\title{
UJI AKTIVITAS ANTIBAKTERI \\ EKSTRAK ETANOI DAUN KAMBOJA (Plumeria $s p$ ) TERHADAP BAKTERI Escherichia coli SECARA IN VITRO
}

\author{
Susanti Erikania ${ }^{1}$, Yetty Hariningsih ${ }^{2}$ \\ 1Program Studi DIII Farmasi, Stikes Bhakti Husada Mulia Madiun \\ 2Program Studi S1 Farmasi, Stikes Bhakti Husada Mulia Madiun \\ E-mail: newerikania@gmail.com
}

\begin{abstract}
ABSTRAK
Tanaman obat menjadi sumber utama ditemukannya senyawa kimia baru yang memiliki khasiat secara farmakologi, salah satunya adalah tanaman kamboja (Plumeria sp). Tanaman kamboja adalah salah satu tanaman tradisional yang dilaporkan mempunyai berbagai khasiat, antara lain daunnya sebagai pencahar, antigatal dan antibakteri, buah dan kulit batangnya dilaporkan berefek antiinflamasi. Tujuan dari penelitian ini adalah mengetahui aktivitas daun kamboja sebagai antibakteri terhadap Escherichia coli secara in vitro. Penelitian ini menggunakan metode difusi cakram dengan 5 kelompok perlakuan meliputi kontrol negatif yaitu DMSO dengan konsentrasi $10 \%$, kontrol positif yaitu kloramfenikol konsentrasi $30 \mu \mathrm{g} / \mathrm{disk}$ dan ekstrak etanol daun kamboja (Plumeria sp) masing-masing sebesar $25 \%$, $50 \%$ dan $100 \%$. Media yang digunakan adalah media nutrient agar (NA). Media steril yang telah diinokulasi dengan Escherichia coli selanjutnya diberi perlakuan dengan kertas cakram yang terdiri dari kontrol negatif, kontrol positif dan sampel, kemudian diinkubasi pada suhu $37^{\circ} \mathrm{C}$ selama 24 jam. Selanjutnya dilakukan pengukuran zona hambat menggunakan jangka sorong. Penelitian menunjukkan adanya zona hambat pada kelompok perlakuan ekstrak etanol daun kamboja pada konsentrasi 25\%, 50\%, $100 \%$ dan kontrol positif, dan tidak tedapat zona hambat pada kelompok perlakuan dengan kontrol negatif. Ekstrak etanol daun kamboja mampu menghambat pertumbuhan Escherichia coli dengan daya hambat minimal adalah konsentrasi $25 \%$ yaitu menghasilkan zona hambat sebesar 7,13 mm, konsentrasi $50 \%$ menghasilkan zona hambat sebesar 10,17 mm dan konsentrasi $100 \%$ memiliki nilai zona hambat paling besar yaitu $14,50 \mathrm{~mm}$.
\end{abstract}

Kata Kunci : Ekstrak etanol daun kamboja, Metode difusi cakram, Streptococcus mutans, Uji aktivitas antibakteri

\begin{abstract}
Medicinal plants are the main source of the discovery of new chemical compounds that have pharmacological properties, one of which is frangipani (Plumeria sp). Frangipani plants are one of the traditional plants that are reported to have various benefits, including laxative, and antibacterial leaves, fruit and bark reported to have anti-inflammatory effects. The purpose of this study was to determine the activity of frangipani leaves as an antibacterial against Escherichia coli in vitro. This study uses a disk diffusion method with 5 treatment groups including negative control, namely DMSO with a concentration of 10\%, positive control that is chloramphenicol concentration of $30 \mu \mathrm{g} /$ disk and ethanol extract of frangipani leaves (Plumeria sp) each by 25\%, 50\% and 100\%. The media used is nutrient agar (NA). Sterile media that have been inoculated with Escherichia coli are then treated with disc paper consisting of negative controls, positive controls and samples, then incubated at $37^{\circ} \mathrm{C}$ for 24 hours. Furthermore, inhibition zone measurements were made using calipers. The study showed that there were inhibitory zones in the treatment group of frangipani leaf ethanol extract at concentrations of 25\%,50\%, 100\% and positive control, and there were no inhibitory zones in the treatment group with negative controls. Ethanol extract of frangipani leaves can inhibit the growth of Escherichia coli with a minimum inhibitory concentration of $25 \%$ which produces a inhibition zone of $7.13 \mathrm{~mm}$, a concentration of $50 \%$ produces an inhibitory zone of $10.17 \mathrm{~mm}$ and a concentration of $100 \%$ has the greatest inhibition zone value of $1450 \mathrm{~mm}$.
\end{abstract}

Keywords: Frangipani leaf ethanol extract, Disc diffusion method, Streptococcus mutans, activity test antibacterial 


\section{PENDAHULUAN}

Indonesia adalah negara beriklim tropis yang kaya akan keanekaragaman hayati sehingga terkenal akan kekayaan flora berupa tanaman obat. Obat tradisional berasal dari bahan alam yang terbukti secara empiris dapat digunakan sebagai upaya preventif, promotif dan rehabilitative (Ningsih DR, 2014). Obat tradisional dari bahan alam memiliki kelebihan dibandingkan obat-obat modern yaitu dinilai lebih aman dari pada penggunaan obat modern. Hal ini disebabkan karena obat tradisional memiliki efek samping yang relatif lebih sedikit dari pada obat modern (Sari, 2006). Salah satu tanaman yang dapat dimanfaatkan untuk upaya penyembuhan penyakit yang disebabkan infeksi adalah tanaman kamboja (Plumeria acuminata). Tanaman ini adalah salah satu tanaman tradisional Indonesia yang pernah dilaporkan mempunyai berbagai khasiat, antara lain daunnya sebagai pencahar dan antigatal, buah dan kulit batangnya dilaporkan berefek antiinflamasi (Gupte et $a l, 2006)$. Sedangkan ekstrak etanol daun kamboja (Plumeria acuminata) dilaporkan memiliki aktivitas sebagai antibakteri pada Streptococcus mutans (Putra AH dkk, 2017) dan Staphylococcus epidermidis (Saputri devita, 2018)

Adapun tujuan dari penelitian ini adalah untuk mengetahui aktivitas antibakteri lainnya dari daun kamboja (Plumeria acuminata) terhadap bakteri Escherichia coli. Dalam penelitian ini, akan dilakukan ekstraksi daun kamboja secara maserasi dengan pelarut etanol 96 $\%$ kemudian dilakukan uji aktivitas antibakteri secara difusi mengetahui Konsentrasi penghambatan paling tinggi dan penentuan golongan senyawa kimia apa saja yang terdapat dalam ekstrak etanol daun kamboja.

\section{METODE}

\section{Alat dan bahan}

Alat yang digunakan adalah beaker glass, erlenmeyer, gelas ukur, aluminium foil, timbangan analitik, oven, rotaryevaporator, batang pengaduk, labu ukur, serbet, sarung tangan, masker, cawan petri, ose bulat, tabung rekasi, rak tabung reaksi dan incubator.

Bahan yang digunakan adalah simplisia daun kamboja, etanol $96 \%$, media nutrient agar, DMSO, Cakram kloramfenikol dan cakram kosong.

\section{Pembuatan ekstrak}

Daun kamboja (Plumeria acuminata), dibersihkan, disortasi kering dan basah, dikeringkan menggunakan oven pada suhu $50{ }^{0} \mathrm{C}$ sampai diperoleh kadar air dibawah 10\%, diserbuk menggunakan blender sampai diperoleh serbuk. 
Serbuk yang diperoleh diekstraksi secara maserasi menggunakan etanol 96 $\%$ selama 3 hari, disaring, dipekatkan menggunakan rotaryevaporator sampai diperoleh ekstrak kental.

\section{Identifikasi fitokimia}

\section{1) Steroid/triterpen.}

Sampel ekstrak kental ditambahkan 20 tetes asam asetat anhidrida dan 1 tetes asam sulfat pekat (pereaksi Liebermann Burchard) terbentuk warna biru atau biru hijau menunjukkan adanya steroid, sedangkan warna merah, merah muda atau ungu menunjukkan adanya triterpenoid (Harborne, 1987).

\section{2) Flavonoid.}

Sampel ditambah dengan sedikit air dalam tabung reaksi, ditambahkan sedikit logam magnesium dan 5 tetes $\mathrm{HCl} 2 \mathrm{~N}$, dipanaskan selama 5-10 menit, disaring panas-panas dan dibiarkan dingin, filtrat ditambah amil alkohol, dikocok kuat. Reaksi positif dengan terbentuknya warna merah pada lapisan amil alkohol (Depkes RI, 1986).

\section{3) Alkaloid.}

Ekstrak dibasakan dengan amonia, ditambahkan kloroform. Cairan kloroform disaring, filtrat ditempatkan dalam tabung reaksi kemudian ditambahkan $\mathrm{HCl} 2 \mathrm{~N}$, dikocok, sampai terjadi pemisahan. Filtrat ditambah pereaksi Dragendorff menunjukkan adanya endapan atau kekeruhan berwarna hingga coklat, dan filtrat lainnya ditambahkan pereaksi Mayer menunjukkan endapan atau kekeruhan berwarna putih.

\section{4) Saponin.}

$1 \mathrm{~g}$ ekstrak ditambah dengan air hangat, dikocok vertikal selama 10 detik, dibiarkan selama 10 detik. Pembentukan busa setinggi $1-10 \mathrm{~cm}$ yang stabil selama tidak kurang dari 10 menit, menunjukkan adanya saponin. Pada penambahan 1 tetes $\mathrm{HCl} 2 \mathrm{~N}$, busa tidak hilang (Depkes RI, 1994).

\section{5) Tanin.}

Sebanyak 200 mg ekstrak dilarutkan dengan $20 \mathrm{ml}$ air panas lalu dikocok hingga homogen. setelah dingin ditambah $\mathrm{FeCl}_{3} 3 \%$ menunjukkan hasil positif jika terbentuk larutan biru kehitaman atau hijau kecoklatan.

\section{Uji aktivitas antibakteri}

1) Pembuatan larutan uji

Dibuat larutan uji dari masing-masing ekstrak yaitu konsentrasi $25 \%, 50 \%$ dan $100 \%$. Larutan uji tersebut dilarutkan dengan DMSO.

2) Uji aktivitas antibakteri

a. Pertama, Pembuatan media agar miring yaitu ditimbang nutrient agar 
(NA) sebanyak 2,8 g ditambahkan $100 \mathrm{ml}$ aquades, dipanaskan menggunakan hot plate sampai mendidih. dituang $5 \mathrm{ml} \mathrm{NA} \mathrm{ke} \mathrm{dalam}$ tabung reaksi steril, disterilkan dalam autoclave selama 15 menit dengan suhu $121^{0} \mathrm{C}$, diletakkan dengan kemiringan yang diinginkan lalu tunggu hingga mengeras.

b. Kedua, penanaman bakteri uji pada media agar miring. Kultur bakteri Escherichia coli diambil menggunakan jarum ose bulat, digoreskan rapat pada media agar miring secara zig-zag dari bawah sampai atas, diinkubasi pada suhu kamar $\left(37^{0} \mathrm{C}\right)$ selama 24 jam.

c. Ketiga pembuatan media nutrient agar (NA). Menimbang media NA sebanyak 20 gram, kemudian ditambahkan aquades $1000 \mathrm{ml}$, diaduk dan dipanaskan menggunakan hot plate, di autoclave selama 15 menit dengan suhu $121^{0} \mathrm{C}$. Kemudian media dituang kedalam cawan petri steril sebanyak $15 \mathrm{ml}$ dan dilakukan di dalam LAF.

d. Keempat uji daya hambat. Merendam cakram kosong selama 5 menit pada masing-masing larutan uji sebagai sampel dan DMSO sebagai kontrol negatif. Kontrol positif yang digunakan adalah kloramfenikol dan dilakukan 3 kali replikasi. Selanjutnya diinkubasi selama 24 jam pada suhu $37^{0} \mathrm{C}$. Amati zona hambatan dengan melakukan pengukuran menggunakan jangka sorong. Diameter zona bening dalam satuan millimeter ( $\mathrm{mm})$ (Romas, Rosyida, \& Aziz, 2015).

b. Analisis data

Analisa data secara statistik, uji distribusi normal (KolmogorovSmirnov) akan digunakan untuk menguji apakah data terdistribusi normal atau tidak. Jika data tidak terdistribusi normal $(\mathrm{p}<0,05)$, maka dilanjutkan dengan uji non parametik. Jika data terdistribusi normal ( $p$ > 0,05), maka dilanjutkan dengan uji parametrik analisis varians satu arah (ANOVA). Uji dilanjutkan dengan tes Post Hoc untuk melihat apakah terdapat perbedaan di antara masingmasing kelompok perlakuan. Sedangkan untuk analisis korelasi antara besarnya zona hambat terhadap aktivitas antibakteri akan dilakukan dengan analisis uji korelasi taraf kepercayaan 95\% (Sugiyono, 2008)

\section{HASIL DAN DISKUSI}

Proses ekstraksi daun kamboja (Plumeria acuminata) dilakukan secara maserasi karena metode ini merupakan metode ekstraksi yang sederhana dengan cara merendam serbuk simplisia dengan pelarut etanol $96 \%$ perbandingan $1: 10$ 
selama 3x 24 jam. Ekstraksi maserasi daun kamboja (Plumeria acuminata) mendapatkan berat ekstrak sebesar 50,22 gram dengan rendemen sebesar 47,76\% yang ditunjukkan pada tabel 3.

Tabel 1. Hasil Ekstraksi

\begin{tabular}{cccc}
\hline No & $\begin{array}{l}\text { Berat } \\
\text { kering } \\
\text { (gram) }\end{array}$ & $\begin{array}{c}\text { Berat } \\
\text { ekstrak } \\
\text { (gram) }\end{array}$ & $\begin{array}{c}\text { Rendemen } \\
(\%)\end{array}$ \\
\hline $\mathbf{1}$ & 105,14 & 50,22 & 47,76 \\
\hline
\end{tabular}

Setelah dilakukan proses ekstraksi, selanjutnya ekstrak etanol daun kamboja diuji fitokimia untuk mengetahui kandungan senyawa-senyawa kimia atau metabolit sekunder didalam ekstrak etanol daun kamboja.

Tabel 2. Hasil skrining fitokimia

\begin{tabular}{lc}
\hline \multicolumn{1}{c}{ Bahan uji } & Ekstrak etanol \\
\hline Alkaloid & + \\
flavonoid & + \\
Tannin & - \\
saponin & + \\
Steroid/triterpen & - \\
\hline
\end{tabular}

\section{Keterangan :}

(+) mengandung metabolit sekunder,

(-) tidak mengandung metabolit sekunder

Hasil uji fitokimia ekstrak etanol daun kamboja (Plumeria acuminata), menunjukkan positif mengandung flavonoid, alkaloid dan saponin. Senyawa flavonoid memiliki aktivitas sebagai antibakteri dengan mekanisme yaitu menghambat sintesis asam nukleat, menghambat fungsi membran sel, dan menghambat metabolisme energi.
Flavonoid menyebabkan terjadinya kerusakan permeabilitas dinding sel bakteri, mikrosom,dan lisosom sebagai hasil interaksi antara flavonoid dengan DNA bakteri (Cushnie dan Lamb, A. J, 2005). Mekanisme kerja flavonoid menghambat fungsi membran sel adalah membentuk senyawa kompleks dengan protein ekstraseluler yang dapat merusak membran sel bakteri dan diikuti dengan keluarnya senyawa intraseluler dan tanin memiliki khasiat atau aktivitas sebagai antioksidan dan antibakteri. Alkaloid sebagai antibakteri dengan mekanisme mengganggu komponen penyusun peptidoglikan pada sel bakteri, sehingga lapisan dinding sel tidak terbentuk secara utuh sehingga menyebabkan kematian sel (Darsana dkk, 2012). Saponin sebagai antibakteri yaitu dapat menyebabkan kebocoran protein dan enzim dari dalam sel. Sedangkan senyawa saponin sebagai antibakteri melalui mekanisme menurunkan tegangan permukaan sehingga mengakibatkan naiknya permeabilitas atau kebocoran sel dan mengakibatkan senyawa intraseluler akan keluar (Nuria dkk, 2009). Saponin mampu berdifusi melalui membran luar dan dinding sel yang rentan kemudian mengikat membran sitoplasma sehingga mengganggu dan mengurangi kestabilan membran sel. Hal ini menyebabkan sitoplasma bocor keluar dari sel yang 
mengakibatkan kematian sel. Agen antimikroba yang mengganggu membran sitoplasma bersifat bakterisida (Rijayanti,2014).
Berdasarkan penelitian yang telah dilakukan diperoleh data sebagai berikut :

Tabel 3. Zona hambat

\begin{tabular}{ccccc}
\hline \multirow{2}{*}{ Bahan Uji } & Konsentrasi (\%) & \multicolumn{3}{c}{ Zona Hambat (mm) } \\
\cline { 3 - 5 } DMSO & $10 \%$ & $\mathrm{I}$ & $\mathrm{II}$ & $\mathrm{III}$ \\
Kloramfenicol & $30 \mu \mathrm{g} / \mathrm{disk}$ & 25,20 & - & - \\
& $25 \%$ & 7,10 & 7,20 & 25,30 \\
Ekstrak etanol daun kamboja & $50 \%$ & 10,20 & 10,22 & 10,19 \\
& $100 \%$ & 14,50 & 14,51 & 14,50 \\
\hline
\end{tabular}

Berdasarkan tabel tersebut, yaitu memberikan zona hambat $10,17 \mathrm{~mm}$ keefektifan aktivitas antibakteri dapat dan konsentrasi tertinggi yaitu $100 \%$ dilihat dari zona hambat yang terbentuk. Davis dan Stout (1971) menjelaskan bahwa klasifikasi respon hambatan pertumbuhan bakteri yang dilihat berdasarkan diameter zona bening terdiri atas 4 kelompok yaitu respon lemah (diameter $\leq 5 \mathrm{~mm}$ ), sedang (diameter 5-10 $\mathrm{mm}$ ), kuat (diameter 10-20 $\mathrm{mm}$ ), dan sangat kuat (diameter $\geq 20 \mathrm{~mm}$ ). Berdasarkan uraian diatas didapatkan hasil bahwa pelarut DMSO tidak memberikan respon terhadap bakteri $E$ coli, sedangkan kontrol positif kloramfenicol memberikan respon kuat pada konsentrasi $30 \mu \mathrm{g} /$ disk dengan diameter zona hambat sebesar 25,17 $\mathrm{mm}$. Sampel uji ekstrak etanol daun kamboja memberikan respon baik pada konsentrasi $25 \%$ yaitu dengan diameter zona hambat sebesar 7,13 mm, pada konsentrasi $50 \%$ memberikan zona hambat $14,50 \mathrm{~mm}$.

Analisis statistik terhadap aktivitas ekstrak etanol daun kamboja yaitu normalitas kolmogorov-smirnov yaitu $\mathrm{p}=$ 0,200 dan Shapiro-wilk yaitu $\mathrm{p}=0,403$ untuk kontrol $(+), p=0,620$ untuk ekstrak adalah > 0,05 memiliki makna bahwa nilai zona hambat semua kelompok uji terdistribusi normal. Test homogenity of variance diperoleh nilai signifikansi (Sig) 0,608 > dari 0,05 memiliki makna varian kelompok uji adalah sama atau homogen. Uji annova diperoleh nilai signifikansi sebesar $0,000<$ dari 0,005 yang memiliki makna rata-rata nilai zona hambat kelompok uji adalah berbeda secara signifikan yaitu kontrol (+) dan ekstrak etanol pada konsentrasi $25 \%, 50 \%$ dan $100 \%$ memiliki aktivitas antibakteri yang berbeda. 


\section{KESIMPULAN}

Berdasarkan penelitian diatas menunjukkan bahwa ekstrak etanol daun kamboja pada konsentrasi $100 \%$ memiliki nilai zona hambat paling besar yaitu 14,50 $\mathrm{mm}$ dibandingkan dengan konsentrasi $25 \%$ yaitu $7,13 \mathrm{~mm}$ dan $50 \%$ yaitu 10, $17 \mathrm{~mm}$.

\section{DAFTAR PUSTAKA}

Cushnie, T. P. T., dan Lamb, A. J. 2005. "Antimicrobial Activity of Flavonoid". International Journal of Antimicrobial Agent. Vol 26: (2005) 343-356

Darsana, I. Besung, I. Mahatmi, H. 2012. Potensi Daun Binahong (Anredera Cordifolia (Tenore) Steenis) dalam Menghambat Pertumbuhan Bakteri Escherichia coli secara In Vitro. Indonesia Medicus Veterinus. 1 (3): 337351

Davis, W. W. dan Stout, T. R. 1971. Disc Plate Method of Microbiological Antibiotic Assay. Applied Microbiology. 22 (4): 659-665

Depkes RI. 1994. Keputusan Menteri Kesehatan Republik Indonesia Nomor:

661/MENKES/SK/VII/1994 tentang Persyaratan Obat Tradisional, Departemen Kesehatan Republik Indonesia, Jakarta

Departemen Kesehatan RI. 1986. Sediaan Galenika. Departemen Kesehatan RI. Jakarta. Hal. 1 - 20

Harborne, J.B. 1987. Metode Fitokimia Penuntun Cara Modern Menganalisis Tumbuhan. Penerbit ITB. Bandung.

Ningsih Dr, Zusfahair dan Purwati, 2014, Potensi Ekstrak Daun Kamboja
(Plumeria Alba L.) Sebagai Antibakteri Dan Identifikasi Golongan Senyawa Bioaktifnya, Universitas Jenderal Soedirman

Nuria, maulita cut, Faizaitun, Arvin, Sumantri. 2009. Uji Aktivitas Antibakteri Ekstrak Etanol Daun Jarak Pagar (Jatropha Curcas L) Terhadap Bakteri Staphylococcus Aureus Atcc 25923, Escherichia Coli Atcc 25922, Dan Salmonella Typhi Atcc 1408, Mediagro. Vol.5: $26-37$.

Putra AH, Yani Corvianindya dan Melok Aris Wahyukundari. 2017. Uji Aktivitas Antibakteri Ekstrak Etanol Daun Kamboja Putih (Plumeria acuminata) Terhadap Pertumbuhan Streptococcus mutans, Fakultas Kedokteran Gigi. Universitas Jember.

Rijayanti, Luliana, Trianto. 2014. Uji Aktivitas Antibakteri Ekstrak Etanol Daun Mangga Bacang (Mangifera foetida L.) Terhadap Staphylococcus aureus. Tanjungpura : Fakultas Kedokteran Universitas Tanjungpura

Romas, A., Rosyida, D. U., \& Aziz, M. A. 2015. Uji Aktivitas Antibakteri Ekstrak Etanol Kulit Buah Manggis (Garcinia Mangostana L) Terhadap Bakteri Echerichia Coli ATCC 11229 Dan Staphylococcus Aureus ATCC 6538 Secara In Vitro. University Research Colloquium 2015.

Sari, L.O.R.K. 2006. Pemanfaatan Obat Tradisional dengan Pertimbangan Manfaat dan Keamanannya, Majalah Ilmu Kefarmasian. Vol. III, No.1, April 2006, 01 - 07 ISSN : 1693-9883.

Saputri devita. 2018. Komparasi Aktivitas Antibakteri Ekstrak Etanol Daun Plumeria alba dan Plumeria rubra terhadap Staphylococcus epidermidis ATCC 12228. Skripsi. UIN Sunan Kalijaga. Yogyakarta 
Sugiyono. 2008. Metode Penelitian

Pendidikan. Bandung : CV.

ALFABETA, hlm. 131, 207 